\title{
Assessment of combining ability for yield and quality components in hot pepper (Capsicum annuum L.)
}

\author{
Narayanasamy Rohini ${ }^{1}$, Valliyappan Lakshmanan ${ }^{1}$, Desabandhu Saraladevi ${ }^{1}$, John J. Amalraj ${ }^{2}$ and Perumal Govindaraju ${ }^{3}$ \\ ${ }^{I}$ Tamil Nadu Agricultural University, Horticultural College and Research Institute, Dept. Vegetable Crops, Periyakulam-625 604, Tamil Nadu, India. \\ ${ }^{2}$ Tamil Nadu Agricultural University, Dept. Plant Genetic Resource, Coimbatore-641003, Tamil Nadu, India \\ ${ }^{3}$ Tamil Nadu Agricultural University, ADAC\&RI, Dept. Soil Science and Agricultural Chemistry, Trichy -620 009, Tamil Nadu, India.
}

\begin{abstract}
Six parental genotypes and their thirty $F_{1}$ hybrids in a full diallel cross system with reciprocals, were used in the present study to estimate combining ability for five quantitative and five qualitative traits in hot pepper. The mean sum of squares due to general combining ability (GCA), specific combining ability (SCA) and reciprocal combining ability (RCA) were significant for all the characters which suggest that these parents could have performed differently in different combinations indicating interallelic interactions. All the traits studied exhibited greater SCA variance than GCA, suggesting that these traits are controlled by non-additive gene action. Analysis of the GCA effects of parents for various traits revealed that LCA625, K1 and PKM1 were the best general combiners for almost all the traits. Estimates of SCA effects showed that the hybrids LCA $625 \times \mathrm{K} 1, \mathrm{~K} 1 \times$ Arka Lohit and Pusa Jwala $\times$ PKM1 were found to be the best combiners for yield and its attributes. The hybrid K1 $\times$ Arka Lohit was the best reciprocal combiner for quality parameters based on its better mean performance and combining ability. These results suggest that commercial production of hot pepper hybrids and isolation of pure lines from these hybrids is a possible way to enhance the yield and fruit quality.
\end{abstract}

Additional key words: chilli; growth; capsaicin; dry yield; GCA; SCA; RCA

Authors' contributions: Designed the study: LV, SD, JJA and GP. Data collection, field work and statistical analysis: RN. Technical and material support: LV and SD. Contributed analysis tools: JJA and GP. All authors read and approved the final manuscript.

Citation: Rohini, N.; Lakshmanan, V., Saraladevi, D., Amalraj, J. J.; Govindaraju, P. (2017). Assessment of combining ability for yield and quality components in hot pepper (Capsicum annuum L.). Spanish Journal of Agricultural Research, Volume 15, Issue 2, e0703. https://doi.org/10.5424/sjar/2017152-10190

Received: 01 Jun 2016 Accepted: 05 Jun 2017

Copyright (C) 2017 INIA. This is an open access article distributed under the terms of the Creative Commons Attribution (CC-by) Spain 3.0 License.

Funding: The authors received no specific funding for this work

Competing interests: The authors have declared that no competing interests exist.

Correspondence should be addressed to Rohini Narayanasamy: rohizna@gmail.com

\section{Introduction}

Hot pepper (Capsicum annuum L.) is the universal vegetable cum spice of India. In India it is cultivated in all the states and union territories of the country. The most important states growing chilli are Andhra Pradesh, Orissa, Maharashtra, West Bengal, Rajasthan and Tamil Nadu. Andhra Pradesh alone commands $46 \%$ of the chilli production in India. As per the latest statistics, India produced $11,000,452$ tonnes of dry chillies from an area of $9,036,028$ hectares. No country in the world has so much area and production of chilli. Almost $90 \%$ of chilli production is consumed indigenously while only $10 \%$ is exported. Demand Hot pepper has two important commercial qualities. Some varieties are famous for red colour because of the pigment capsanthin, others are known for biting pungency attributed by capsaicin. India is the only country rich in many varieties with different quality factors. In the world, both domestic consumption and export are maximum in India. As a product, oleoresin of hot pepper with low, medium or high pungency is also exported in large quantities (Manjula et al., 2011). Chilli powder is another important product of export. Indian chillies and its products are brought out by many countries, viz., Sri Lanka, Bangladesh, South Korea and USA for dry chillies and USA, Germany, Japan, UK and France for oleoresin. India can supply chilli as in whole, crushed, powder or oleoresin forms in consistent colour and required pungency (Sharanakumar et al., 2011). 
Hot peppers have been standing out by their increasing preference in the consumer market. Even though increase in cultivation and commercialization of hot pepper in the last few years (Nascimento et al., 2014) there is increasing demand in India for new cultivars that have higher yield, quality, pest and disease resistance, all of which can be achieved through breeding programmes.

Diallel analysis is a biometrical tool that provides the estimates of genetic parameters regarding heterosis and combining ability. It gives additional information on presence or absence of epistasis, average degree of dominance and distribution of dominant and recessive genes in the parents (Rego et al., 2011; Nascimento et al., 2014). Application of diallel techniques to selfpollinated crops for improving yield and quality may be appropriate (Griffing, 1956). The concept of combining ability was developed by Sprague \& Tatum as early as 1942. According to them, the general combining ability (GCA) is the comparative ability of the lines or parents to combine with other lines. Specific combining ability (SCA) is the deviation in the performance of a specific cross from the performance expected on the basis of GCA effects of the parents involved in the cross. The expression of heterosis is highly associated with SCA of crosses.

Study of combining ability is useful in predicting the performance of hybrid. Simultaneously the genetic distance also plays a major role in to assess the hybrid vigour component (e.g. Rodríguez et al., 2003, 2008). Hence, combining ability analysis is extensively used to study nature and magnitude of genotypic variability and facilitate correct choice of desirable parents in a hybrid development programme. The knowledge of gene effects on expression of any trait greatly helps the plant breeder in making to draw strategies of breeding population, selection method, type of variety and extent of testing. Combining ability analysis also gives a clear picture of elite parent which can be fitted as a general combiner over a series of cross combinations and in a specific cross to exploit heterosis.

Roja \& Sprague (1952) and Griffing (1956) stated that the GCA includes the additive genetic portion, while SCA includes non-additive genetic portion of the total variation. Hayman (1957) found that in the absence of epistasis, GCA is composed of both additive and dominance while SCA involves mainly dominance effects. Extensive work has been done in chilli by various research workers on the combining ability of the exotic and indigenous genotypes for various characters. Jagadeesha \& Wali (2008) studied 18 divergent lines and $45 \mathrm{~F}_{1}$ hybrids and reported that the parents VN2, BKaddi, Arka Lohit, Phule5 and LCA312 exhibited high GCA which may be utilized in recurrent selection programme for improvement in fruit quality traits. Rego et al. (2009) crossed eight lines of Capsicum baccatum in a complete diallel and revealed that GCA effects of the parents and SCA effects of the crosses were significant. Khalil \& Hatem (2014) evaluated six parents and 15 hybrids for yield and quality traits and found significant variance for all the traits. Estimates of GCA effects showed that the best combiner parents were found to be those of W515 and Big Dipper for fruits number, W515 and LS22 for total yield as fruits number and weight, Big Dipper for fruit diameter. For pericarp thickness and ascorbic acid content, the parental genotype Big Dipper was the best combiner, while LS22 for total soluble solids content. Estimates of SCA effects showed that the $\mathrm{F}_{1}$ cross Big Dipper $\times$ B1610 reflected the highest value in all traits. From this prospective, the objective of the study was to estimate the general combining ability (GCA), specific combining ability (SCA) and reciprocal effects using each five quantitative and qualitative traits and to determine the most promising crosses for exploiting heterosis among the six parents.

\section{Material and methods}

The experiment was conducted in the Department of Vegetable Crops, Horticultural College and Research Institute, Tamil Nadu Agricultural University, Periyakulam, India during 2013-2015. Six homozygous inbreds viz., Arka Lohit (P1), K1 (P2), LCA334 (P3), LCA625 (P4), PKM1 (P5) and Pusa Jwala (P6) were used as parents and the promising hybrid $\mathrm{CO} \mathrm{CH} 1$ obtained from Department of Vegetable Crops, TNAU, Coimbatore was used as standard check (Table 1). The parents were crossed in all possible combinations, both direct and reciprocal (full diallel), to get the maximum number of hybrids. The pollen was collected from each male parent as soon as the flower buds were opened. The flower buds from plants of six female parents were emasculated in the last day evening and covered with coloured bags. In the morning, to pollinate, pollen grains from each one of the stigma of each emasculated flowers. Labels were used to identify the fruits from each different type of crosses.

The parents and progeny seeds were treated 24 hours before sowing with $4 \mathrm{~g}$ of Trichoderma asperellum var. viride, and sowed in 98 cells portrays. Seeds were watered with rosecan to facilitate quick germination and good growth of seedlings. The main field was prepared to a fine tilth and $25 \mathrm{t} / \mathrm{ha}$ of FYM was applied at the last ploughing. Prior to transplanting, at the time of field preparation about $2 \mathrm{~kg} / \mathrm{ha}$ of Azospirillum and Phosphobacteria each were mixed with $20 \mathrm{~kg}$ of FYM and $30: 60: 30 \mathrm{~kg} / \mathrm{ha}$ NPK in the form of urea, single 
Table 1. The outstanding attributes of the parents and check used for the study

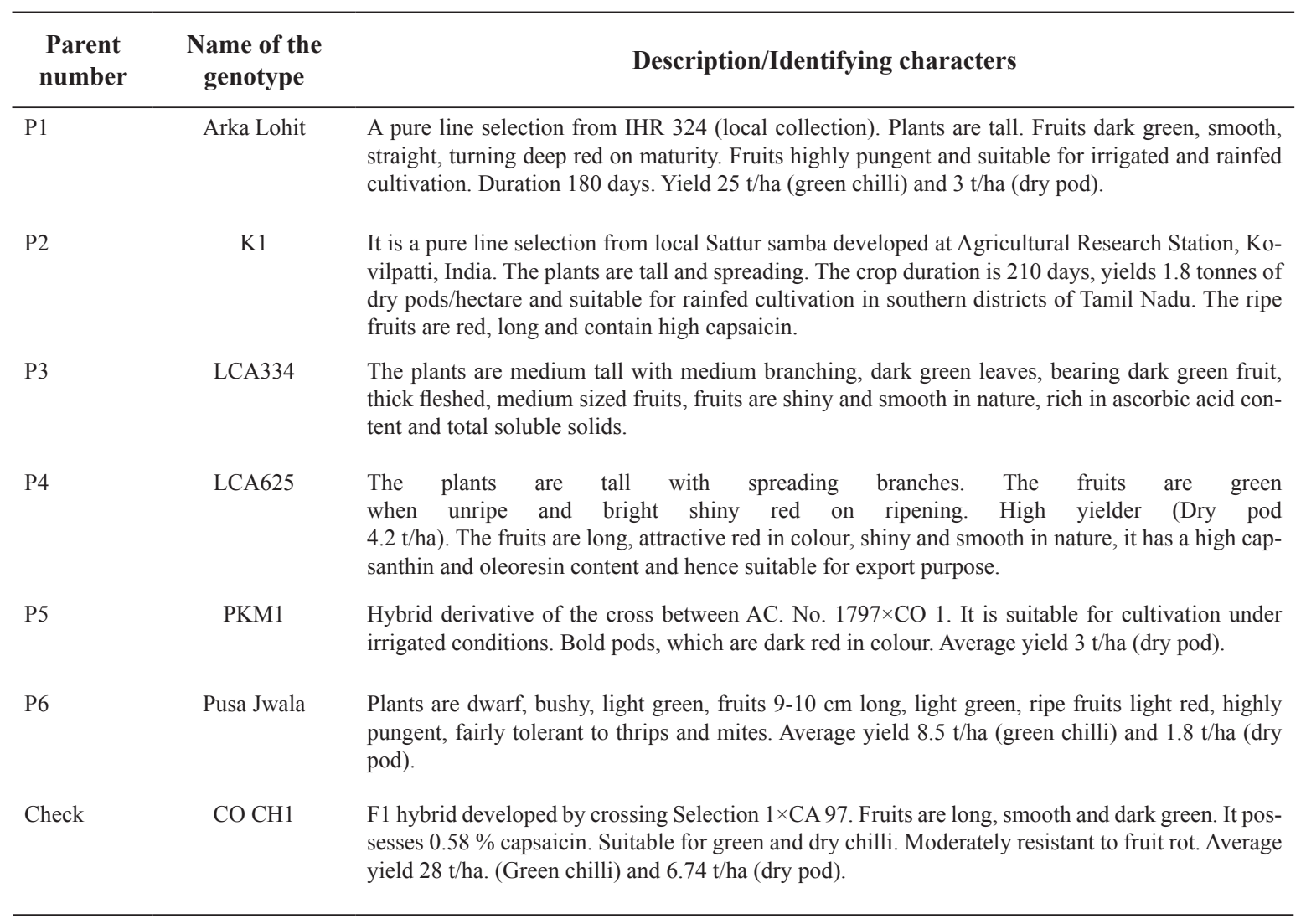

super phosphate and muriate of potash, respectively was applied to the soil. The seedlings were transplanted in the second week of November 2013. Seedlings with age of 45 days old were transplanted with a plant spacing of $45 \mathrm{~cm}$ at the rate of one seedling. Fifty plants of each of the thirty $F_{1} s$, six of parents were planted at a distance of $60 \times 45 \mathrm{~cm}$ in a randomized block design with three replications during November 2014 to April 2015 . Additionally $30 \mathrm{~kg} \mathrm{~N} / \mathrm{ha}$ was given in equal splits on 30,60 and 90 days after planting. Soil moisture was maintained during the growing season with flood irrigation at 5 days intervals. The recommended package of practices including plant protection measures obligatory to raise the good crop were followed in field (CPG, 2013).Data were collected from individual plants of $F_{1}$ generation of hot pepper for each five quantitative traits viz., branches per plant, fruits per plant, fruit shape, individual dry pod weight, dry pod yield per plant.

The observation for five quality characters were recorded from fifteen competitive plants selected randomly from each replication. The ascorbic acid content of hot pepper pod was estimated as per the standard procedure (Sadasivam \& Manickam, 1992) and expressed in $\mathrm{mg} / 100 \mathrm{~g}$. The capsaicin content (\%) of dry pod was estimated adopting the procedure given by Sadasivam \& Manickam (1992). The extractable colour in hot pepper was estimated as per the procedure of Woodbury (1997) and expressed in ASTA units. Oleoresin content was analysed as per the procedure of Mathai (1988). A drop of juice was used to record the total soluble solid ( ${ }^{\circ}$ Brix) with the help of hand refractometer.

\section{Statistical analysis}

The statistical parameters like mean, range were calculated as per the standard methods of analysis (Panse \& Sukhatme, 1957).

\section{Diallel analysis}

A diallel analysis was cried out using the data of six parents and resultant thirty $F_{1}$ hybrids. "Null hypothesis' was tested to show that there were no genotypic differences among the progenies. This was worked out using randomized block design. In randomized block design three sources were used viz., blocks, genotypes and error. For blocks (b) the degree of freedom was (b-1), the degrees of freedom for genotypes was ( $\mathrm{g}-1)$. In genotypes the results is expected as $s^{2} e$ (error variance) $+s^{2} g$ (genotypic variance). The degree of freedom for error was reported as (b-1) (g-1) and their result is expected as $\mathrm{s}^{2} \mathrm{e}$. 


\section{Griffing's combining ability analysis}

Estimation of general and specific combining ability was done by following Griffing (1956b) method I of diallel analysis, which included parents, $\mathrm{F}_{1} \mathrm{~s}$ and reciprocals.

\section{General combining ability effect (GCA)}

$$
g i=1 \because 2 p(X i .+X . i) 1 \therefore p 2 * X .
$$

where $\mathrm{p}=$ number of parent; $\mathrm{Xi}$. $=$ row total of parents in the array; $\mathrm{X} . \mathrm{i}=$ column total of parents in the array $\mathrm{M}$, $\mathrm{x} ; \mathrm{X} . .=$ grand total of diallel table.

\section{Specific combining ability effects (SCA)}

$S i j=\frac{1}{2}(X i j+X j i)-\frac{1}{2 p}(X i .+X . i+X j .+X . j)+\frac{1}{p 2} X .$.

$S i j=\frac{1}{2}(X i j+X j i)-\frac{1}{2 p}(X i .+X . i+X j .+X . j)+\frac{1}{p 2} X$.

where $\mathrm{p}=$ number of parents; Xij= array means of $\mathrm{F} 1$; $\mathrm{Xji}=$ array means of reciprocal $\mathrm{F}_{1} ; \mathrm{Xi} .=$ row total of first parent; X.i = column total of first parent; $\mathrm{Xj} .=$ row total of second parent; X.j = column total of second parent; $\mathrm{X} . .=$ grand total of diallel table.

\section{Reciprocal effects (RCA)}

$$
r i j=\frac{1}{2}(X i j+X j i)
$$

The variances of these effects were estimated as follows:

$$
\begin{gathered}
\operatorname{Var}(g i)=p-\frac{1}{2 p 2} \quad \sigma 2 e \\
\operatorname{Var}(\operatorname{sij})=\frac{1}{2}(p 2-2 p+2) \sigma 2 e \\
\operatorname{Var}(r i j)=\frac{1}{2} \sigma 2 e
\end{gathered}
$$

The square root of the variance provides the corresponding standard error for calculating critical differences.

\section{Results and discussion}

\section{GCA effects of the parents}

The success of any plant breeding programme greatly depends on right choice of parents. The potential of a variety is judged by comparing the mean performance and combining ability of the parents (Singh, 1994). Kadambavanasundaram (1980) suggested that the parents with high per se performance may not always be able to transmit their superior traits into hybrids and so assessment of combining ability is most needed. General combining ability (GCA) of a parent is a factor that predicts the performance of a parent over a series of cross combinations. Since GCA of a genotype is due to additive and additive $\times$ additive interaction effects, the ultimate goal of any breeder could be either to produce a variety which is homozygous for all the desired genes or to develop such parents that would produce superior hybrid. Thus combining ability assumes greater importance to assess the genetic potentialities of a genotype. Dhillon (1975) had also pointed out that the combining ability had given useful information on the choice of parents in form of expected performance of the hybrids and their progenies. The combining ability studies in the present investigation revealed that the parents possessed high GCA effects for different characters. Based on the GCA effects, the best parents identified as good combiners for various characters are furnished in Table 2.

At present, development of high yielding hybrids along with quality enhancement is aimed in vegetable improvement programme. Parents with high per se and significant GCA for various characters have been highlighted in Table 3. In this study some of the parents are good general combiners for yield and quality contributing characters. From this table, it is obvious that the parents ranking top in per se did not necessarily appear as top rankers when GCA effect was considered. However, for certain traits there was considerable agreement between per se and GCA of parents. Estimates of general combining ability value for the parental lines showed that the best inbreds for

Table 2. Parents with high and significant GCA effect for yield and quality traits

\begin{tabular}{ll}
\multicolumn{1}{c}{ Parent } & \multicolumn{1}{c}{ Character } \\
\hline Arka Lohit & Capsaicin, total soluble solids \\
K1 & Branches per plant \\
LCA334 & Fruits per plant, individual dry pod \\
LCA625 & weight, ascorbic acid, oleoresin \\
PKM1 & Fruit shape \\
Pusa Jwala & Capsaicin, colour value \\
\hline
\end{tabular}


Table 3. Mean performance and general combining ability effects of parents for yield and quality characters

\begin{tabular}{|c|c|c|c|c|c|c|c|c|c|c|}
\hline \multirow{2}{*}{ Parents } & \multicolumn{2}{|c|}{ Branches /plant } & \multicolumn{2}{|c|}{ Fruits /plant } & \multicolumn{2}{|c|}{ Fruit shape } & \multicolumn{2}{|c|}{ Dry pod weight } & \multicolumn{2}{|c|}{ Dry pod yield } \\
\hline & Mean & GCA & Mean & GCA & Mean & GCA & $\begin{array}{c}\text { Mean } \\
\text { (g) }\end{array}$ & GCA & $\begin{array}{c}\text { Mean } \\
\text { (g) }\end{array}$ & GCA \\
\hline Arka Lohit & 7.28 & 0.03 & 98.48 & $-1.51 * *$ & 3.28 & 0.02 & 0.75 & $0.01 *$ & 73.50 & -1.08 \\
\hline $\mathrm{K} 1$ & $8.53 \mathrm{~W}$ & $0.53 * *$ & 92.00 & $6.93 * *$ & 2.58 & $0.10 * *$ & 0.54 & $0.03 * *$ & 49.68 & $9.74 * *$ \\
\hline LCA334 & 7.00 & $-1.04 * *$ & 86.52 & $-19.27 * *$ & 2.72 & $-0.11 * *$ & 0.62 & $-0.07 * *$ & 55.18 & $-22.30 * *$ \\
\hline LCA625 & 8.95 & $0.47 * *$ & 104.75 & $8.76^{* *}$ & 3.07 & -0.02 & 0.78 & $0.04 * *$ & 81.11 & $10.54 * *$ \\
\hline PKM1 & 8.52 & -0.02 & 80.08 & $3.95 * *$ & 3.10 & $0.12 * *$ & 0.66 & 0.001 & 53.03 & $3.98 * *$ \\
\hline Pusa Jwala & 9.38 & 0.01 & 90.85 & $1.22 * *$ & 2.30 & $-0.12 * *$ & 0.72 & $-0.01 * *$ & 64.80 & -0.88 \\
\hline SE (gi) & -- & 0.110 & -- & 0.117 & -- & 0.018 & -- & 0.006 & -- & 0.613 \\
\hline SE d & 0.590 & -- & 0.632 & -- & 0.099 & -- & 0.035 & -- & 62.88 & -- \\
\hline \multirow[t]{3}{*}{$\mathrm{CD}(p=0.05)$} & 1.77 & -- & 1.260 & -- & 0.199 & -- & 0.071 & -- & 103.96 & -- \\
\hline & \multicolumn{2}{|c|}{ Ascorbic acid } & \multicolumn{2}{|c|}{ Capsaicin } & \multicolumn{2}{|c|}{ Colour value } & \multicolumn{2}{|c|}{ Oleoresin } & \multicolumn{2}{|c|}{ Total soluble solids } \\
\hline & $\begin{array}{c}\text { Mean } \\
(\mathrm{mg} / 100 \mathrm{~g})\end{array}$ & GCA & $\begin{array}{c}\text { Mean } \\
(\%)\end{array}$ & GCA & $\begin{array}{c}\text { Mean } \\
\text { (ASTA) }\end{array}$ & GCA & $\begin{array}{c}\text { Mean } \\
(\%)\end{array}$ & GCA & $\begin{array}{l}\text { Mean } \\
\text { ( }{ }^{\circ} \text { Brix) }\end{array}$ & GCA \\
\hline Arka Lohit & 123.41 & $-0.72 *$ & 0.71 & $0.04 * *$ & 71.82 & $-3.30 * *$ & 14.58 & $0.38 * *$ & 6.30 & $0.29 * *$ \\
\hline $\mathrm{K} 1$ & 120.28 & $-1.75 * *$ & 0.53 & $0.01 *$ & 58.59 & -1.10 & 12.47 & $-0.19 * *$ & 5.63 & $-0.11^{*}$ \\
\hline LCA334 & 108.37 & $-2.21 * *$ & 0.49 & $-0.06^{* *}$ & 67.80 & $-4.77 * *$ & 13.18 & $-0.26^{* *}$ & 7.10 & $-0.11^{*}$ \\
\hline LCA625 & 116.55 & $8.66^{* *}$ & 0.66 & 0.00 & 78.18 & $7.74 * *$ & 14.61 & $0.62 * *$ & 5.86 & $0.25 * *$ \\
\hline PKM1 & 79.54 & $-10.60 * *$ & 0.50 & $-0.03 * *$ & 46.78 & $-8.25 * *$ & 12.69 & $-0.38 * *$ & 4.83 & $-0.43 * *$ \\
\hline Pusa Jwala & 112.85 & $6.64 * *$ & 0.75 & $0.04 * *$ & 81.70 & $9.68 * *$ & 13.56 & $-0.15^{*}$ & 6.26 & $0.11 *$ \\
\hline SE (gi) & -- & 0.320 & -- & 0.004 & -- & 0.591 & -- & 0.063 & -- & 0.049 \\
\hline SE d & 0.009 & -- & 0.022 & -- & 0.229 & -- & 8.299 & -- & 3.294 & -- \\
\hline $\mathrm{CD}(p=0.05)$ & 0.018 & -- & 0.043 & -- & 0.456 & -- & 16.553 & -- & 6.571 & -- \\
\hline
\end{tabular}

* Significant at $5 \%$ level. ** Significant at $1 \%$ level

each characters are as follows: K1 (P2), LCA625 (P4) for branches per plant, LCA625 (P4), K1 (P2) for fruit number, K1 (P2), PKM1 (P5) for fruit shape, K1 (P2), LCA625 (P4) for dry pod weight, LCA625 (P2), K1 (P2) for dry pod yield, LCA625 (P4), Pusa Jwala (P6) for ascorbic acid, Arka Lohit (P1), Pusa Jwala (P6) for capsaicin, Pusa Jwala (P6), LCA625 (P4) for colour value, LCA625 (P4), Arka Lohit (P1) for oleoresin and LCA625 (P4), Arka Lohit (P1) for total soluble solids. By and large, the parent LCA625 (P4) had highly significant GCA for eight characters (Table 4). For most of the characters, its mean values also corresponded with high magnitude of its GCA. The parent LCA625 (P4) could be employed in breeding programme for overall improvement. The next best choice would be K1 (P2) which had significant GCA for five characters. This parent will be a better choice when the aim is primarily to increase the fruiting characters. Involving these parents in hybridization would result in the identification of superior hybrid combinations with favourable genes and interactions for the various traits since they are under the influence of additive genes. If a parent possessed significant GCA effects for as many traits as possible, it is well chosen for hybridization rather than parents with low GCA effects or based on mean performance. The other parent chosen for hybridization should possess favourable GCA effects for other traits, so that favourable recombinants for all the traits could be obtained. If only one trait is to be improved, both the parents should have desirable gene effects for the trait. This assumption is based on the principle that additive gene action is reflected by gene effects (Sprague \& Tatum, 1942). Certain parents which performed well by their mean performance but failed to exhibit high GCA effects. Such low association suggests non-additive gene effects in those parents which are evidenced by higher SCA variances than GCA variances. This finding agrees with that reported by Khalil \& Hatem (2014). 
Table 4. Best performing parents based on per se values and GCA effect in chilli

\begin{tabular}{lccc}
\hline \multicolumn{1}{c}{ Characters } & per se & GCA & per se and GCA \\
\hline Branches /plant & Pusa Jwala, LCA625 & K1, LCA625 & K1 \\
Fruits/plant & LCA625, Arka Lohit & LCA625, K1 & LCA625, K1 \\
Fruit shape & Arka Lohit, PKM1 & K1, PKM1 & PKM1 \\
Individual dry pod weight & LCA625, Arka Lohit & K1, LCA625 & LCA625, Arka Lohit \\
Dry pod yield/plant & LCA625, Arka Lohit & LCA625, K1 & LCA625 \\
Ascorbic acid & Arka Lohit, K1, LCA625 & LCA625, Pusa Jwala & LCA625 \\
Capsaicin & Pusa Jwala, Arka Lohit & Arka Lohit, Pusa Jwala & Arka Lohit, Pusa Jwala \\
Colour value & Pusa Jwala, LCA625 & Pusa Jwala, LCA625 & Pusa Jwala, LCA625 \\
Oleoresin & LCA625, Arka Lohit & LCA625, Arka Lohit & LCA625, Arka Lohit \\
Total soluble solids & LCA334, Arka Lohit & LCA625, Arka Lohit & LCA625, Arka Lohit \\
\hline
\end{tabular}

\section{Evaluation of hybrids based on specific combining ability and reciprocal effects}

The estimated results of the analysis of variance for general and specific combing abilities and reciprocal combining effects are presented in Table 5 . The estimates of GCA and SCA variances help to infer the type of gene action and relative importance of the character expression in breeding programme. Magnitude of SCA variance was greater than GCA variance for all the quality traits, indicating the preponderance role of nonadditive type of gene action in the expression of these traits. The results of the present study are in consonance to the findings of Khereba et al. (2008) and Jaya Rame Gowda (2009).

The hybrid $\mathrm{P}_{1} \times \mathrm{P}_{3}$ was the best performing for branches per plant on the basis of their SCA effects and mean values (Table 7) and this hybrid was based on low $\times$ low GCA effects. The reciprocal hybrids $\mathrm{P}_{4} \times \mathrm{P}_{2}$, $\mathrm{P}_{3} \times \mathrm{P}_{1}$ and $\mathrm{P}_{6} \times \mathrm{P}_{5}$ were the best performing on the basis of

Table 5. Analysis of variance for combining ability mean squares in chilli

\begin{tabular}{lrrr}
\hline \multicolumn{1}{c}{ Characters } & \multicolumn{1}{c}{ GCA } & \multicolumn{1}{c}{ SCA } & \multicolumn{1}{c}{ RCA } \\
\hline Branches /plant & $3.86^{* *}$ & $2.98^{* *}$ & $3.02^{* *}$ \\
Fruits/plant & $1238.70^{* *}$ & $571.55^{* *}$ & $1307.90^{* *}$ \\
Fruit shape & $0.13^{* *}$ & $0.07^{* *}$ & $0.16^{* *}$ \\
Dry pod weight & $0.02^{* *}$ & $0.002^{* *}$ & $0.014^{* *}$ \\
Dry pod yield/plant & $1731.32^{* *}$ & $511.64^{* *}$ & $1501.16^{* *}$ \\
Ascorbic acid & $576.48^{* *}$ & $454.02^{* *}$ & $303.37^{* *}$ \\
Capsaicin & $0.024^{* *}$ & $0.007^{* *}$ & $0.006^{* *}$ \\
Colour value & $616.00^{* *}$ & $240.41^{* *}$ & $68.02^{* *}$ \\
Oleoresin & $1.95^{* *}$ & $0.65^{* *}$ & $1.04^{* *}$ \\
Total soluble solids & $0.92^{* *}$ & $0.58^{* *}$ & $0.25^{* *}$ \\
\hline
\end{tabular}

* Significant at $5 \%$ level. $* *$ Significant at $1 \%$ level their RCA effect and mean values and these reciprocal hybrids were the consequential of high $\times$ high, low $\times$ low and low $\times$ low GCA effects. The per se performance was found to be high for reciprocal cross $\mathrm{P} 4 \times \mathrm{P} 2$ and this cross showed the role of additive $\times$ additive gene action. Such combinations could be used for selecting recombinants as pure lines in the later generations. Additive gene action for this trait was also reported by Asish Ghosh (2005).

The selection for high yielding genotype should be based mainly on the fruits per plant (Gill et al., 1973). The hybrids $\mathrm{P}_{1} \times \mathrm{P}_{3}$ and $\mathrm{P}_{2} \times \mathrm{P}_{3}$ were found to be superior based on their SCA effects and per se performance for fruits per plant and all these hybrids were the outcome of low $\times$ low GCA effects of their respective parents. The reciprocal hybrids viz., $\mathrm{P}_{4} \times \mathrm{P}_{2}, \mathrm{P}_{6} \times \mathrm{P}_{5}$ and $\mathrm{P}_{5} \times \mathrm{P}_{4}$ were found to be superior ones based on their SCA effects and per se performance for number of fruits per plant (Table 7) and all these hybrids were the outcome of high $\times$ high GCA effects of their respective parents. The per se performance was found to be high for reciprocal crosses $\mathrm{P}_{4} \times \mathrm{P}_{2}, \quad \mathrm{P}_{5} \times \mathrm{P}_{4}$ and $\mathrm{P}_{6} \times \mathrm{P}_{5}$. All these three hybrids were good combiners with high $\times$ high parental GCA effects suggesting the influence of additive $\times$ additive gene effects on these hybrids. Hence, these parents appeared to be worthy in varietal improvement programme. It was suggested that population involving these parents, in multiple crossing programme, might be developed for isolating desirable lines. Thus, the present studies are in accordance with the outcomes of Jagadeesha \& Wali (2008), Prasath \& Ponnuswami (2008) and Sitaresmi et al. (2010).

Best performing hybrids for fruit shape based on SCA effects were $\mathrm{P}_{1} \times \mathrm{P}_{3}$ and $\mathrm{P}_{1} \times \mathrm{P}_{4}$ and these hybrids were the outcome of low $\times$ low GCA effects of their corresponding parents (Table 7). The hybrids viz., $\mathrm{P}_{6} \times \mathrm{P}_{2}, \mathrm{P}_{3} \times \mathrm{P}_{1}$ and $\mathrm{P}_{6} \times \mathrm{P}_{5}$ were the high performing hybrids based on RCA effects and all these hybrids 
Table 6. Estimates of genetic components of variation for various traits in chilli

\begin{tabular}{lcccc}
\hline \multicolumn{1}{c}{ Characters } & $\boldsymbol{\sigma}^{2}$ GCA & $\boldsymbol{\sigma}^{2}$ SCA & $\boldsymbol{\sigma}^{2}$ RCA & $\boldsymbol{\sigma}^{2}$ GCA : $\boldsymbol{\sigma}^{2}$ SCA \\
\hline Branches/plant & 0.307 & 2.847 & 1.404 & 0.107 \\
Fruits/plant & 103.20 & 1307.704 & 285.67 & 0.078 \\
Fruit shape & 0.010 & 0.163 & 0.037 & 0.067 \\
Dry pod weight & 0.001 & 0.014 & 0.001 & 0.114 \\
Dry pod yield/plant & 143.82 & 1495.73 & 253.11 & 0.096 \\
Ascorbic acid & 47.91 & 301.89 & 226.27 & 0.158 \\
Capsaicin & 0.002 & 0.005 & 0.003 & 0.356 \\
Colour value & 50.91 & 235.37 & 31.489 & 0.216 \\
Oleoresin & 0.157 & 0.592 & 0.495 & 0.265 \\
TSS & 0.074 & 0.545 & 0.109 & 0.136 \\
\hline
\end{tabular}

$\sigma^{2} \mathrm{GCA}$ : variance due to $\mathrm{GCA} \sigma^{2} \mathrm{SCA}$ : variance due to SCA $\sigma^{2} \mathrm{RCA}$ : variance due to RCA

were the outcome of low $\times$ high, low $\times$ low and low $\times$ high GCA effects of their respective parents. These hybrids involved one good and one poor combiner showing dominance $\times$ additive gene action which could be exploited by conventional breeding procedures such as pedigree selection. Jagadeesha \& Wali (2008) observed dominance, additive and duplicate complementary epitasis as common type of gene action for fruit shape.

For individual dry pod weight, the hybrids surpassed based on the highest SCA effect were $\mathrm{P}_{2} \times \mathrm{P}_{6}, \mathrm{P}_{1} \times \mathrm{P}_{5}$ and $\mathrm{P}_{2} \times \mathrm{P}_{5}$ and all these hybrids were the outcome of high $\times$ low $\mathrm{GCA}$ effects of their corresponding parents. The reciprocal hybrids viz., $\mathrm{P}_{6} \times \mathrm{P}_{5}, \mathrm{P}_{6} \times \mathrm{P}_{2}$ and $\mathrm{P}_{3} \times \mathrm{P}_{1}$ were the best performing hybrids based on RCA effects and these hybrids were the outcome of low $\times$ low, low $\times$ high and low $\times$ high GCA effects of their respective parents (Table 7). Interestingly, the per se performance was found to be high for reciprocal cross $\mathrm{P}_{6} \times \mathrm{P}_{5}$ which clearly indicated the significance of cytoplasmic effects controlling these trait and suggesting dominance $\times$ additive and dominance $\times$ dominance type of interaction for individual fresh fruit and individual dry pod weight. This cross could be effectively used to exploit the reciprocal differences for dry pod weight. Hence, these parents involved in the above mentioned crosses appeared to be worthy in the varietal improvement programme. It was also suggested that population involving these parents, in multiple crossing programme, might be developed for isolating desirable lines. Prasath \& Ponnuswami (2008);
JayaRame Gowda (2009); Sitaresmi et al. (2010); Savitha (2011) were of the opinion that the weight of fruits in chillies was governed by both additive and non additive gene effects.Dry pod yield per plant forms the major objective of the present study and the breeding procedures are focused on increasing the potentiality of this trait. The hybrids $\mathrm{P}_{1} \times \mathrm{P}_{3}$ and $\mathrm{P}_{2} \times \mathrm{P}_{3}$ were found to be superior ones based on their SCA effects for dry pod yield per plant and these hybrids were the product of low $\times$ low, and high $\times$ low GCA effects of their parents. The reciprocal hybrids viz., $\mathrm{P}_{6} \times \mathrm{P}_{2}$ and $\mathrm{P}_{6} \times \mathrm{P}_{5}$ had the low $\times$ high GCA combination resulting in high positive significant SCA suggesting dominant $\times$ additive gene interaction. The hybrids, $\mathrm{P}_{4} \times \mathrm{P}_{2}, \mathrm{P}_{5} \times \mathrm{P}_{4}$ and $\mathrm{P}_{2} \times \mathrm{P}_{1}$ were the best performing hybrids based on RCA effects (Table 7) and these hybrids were the outcome of high $\times$ high, high $\times$ high and high $\times$ low GCA effects of their respective parents. The per se performance was found to be high for reciprocal cross $\mathrm{P}_{4} \times \mathrm{P}_{2}$, this cross showed additive $\times$ additive type of interaction. Hence, it was clearly indicated the significance of cytoplasmic effects controlling this trait and crosses could be effectively used to exploit the reciprocal differences. According to Thakur et al. (1980), 12 pairs of genes were responsible for governing this character. These results are in accordance with the outcomes of Khereba et al. (2008) and Somashekhar et al. (2008).

The high performing hybrids for ascorbic acid based on SCA effects were $\mathrm{P}_{3} \times \mathrm{P}_{6}, \mathrm{P}_{2} \times \mathrm{P}_{3}$ and $\mathrm{P}_{1} \times \mathrm{P}_{3}$ (Table 8) 
Table 7. Per se performance and specific combining ability effects of direct and reciprocal crosses for yield traits

\begin{tabular}{|c|c|c|c|c|c|c|c|c|c|c|}
\hline \multirow{3}{*}{ Hybrids } & \multicolumn{2}{|c|}{ Branches /plant } & \multicolumn{2}{|c|}{ Fruits /plant } & \multicolumn{2}{|c|}{ Fruit shape } & \multicolumn{2}{|c|}{ Dry pod weight } & \multicolumn{2}{|c|}{ Dry pod yield/plant } \\
\hline & \multicolumn{10}{|c|}{ Direct crosses (SCA) } \\
\hline & Mean & $\begin{array}{l}\text { SCA/ } \\
\text { RCA }\end{array}$ & Mean & $\begin{array}{l}\text { SCA/ } \\
\text { RCA }\end{array}$ & $\begin{array}{c}\text { Mean } \\
(\mathrm{cm})\end{array}$ & $\begin{array}{l}\text { SCA/ } \\
\text { RCA }\end{array}$ & $\begin{array}{c}\text { Mean } \\
\text { (g) }\end{array}$ & $\begin{array}{l}\text { SCA/ } \\
\text { RCA }\end{array}$ & Mean (g) & $\begin{array}{l}\text { SCA/ } \\
\text { RCA }\end{array}$ \\
\hline $\mathrm{P} 1 \times \mathrm{P} 2$ & 9.20 & $-1.50 * *$ & 127.67 & $-23.68 * *$ & 2.85 & $-0.55 * *$ & 0.80 & $-0.05 * *$ & 98.28 & $-29.48 * *$ \\
\hline $\mathrm{P} 1 \times \mathrm{P} 3$ & 13.50 & $3.25 * *$ & 173.80 & $36.13 * *$ & 3.63 & $0.28 * *$ & 0.84 & -0.00 & 143.10 & $36.45 * *$ \\
\hline $\mathrm{P} 1 \times \mathrm{P} 4$ & 9.00 & $-0.66^{*}$ & 132.85 & 0.42 & 3.29 & $0.35^{* *}$ & 0.83 & $0.03 *$ & 102.28 & 1.50 \\
\hline $\mathrm{P} 1 \times \mathrm{P} 5$ & 8.20 & 0.03 & 106.52 & $-19.24 * *$ & 3.23 & 0.00 & 0.70 & $0.05 * *$ & 73.51 & $-6.58 * *$ \\
\hline $\mathrm{P} 1 \times \mathrm{P} 6$ & 8.63 & -0.55 & 125.50 & $-9.82 * *$ & 2.95 & $-0.11^{*}$ & 0.68 & 0.03 & 85.63 & -1.80 \\
\hline $\mathrm{P} 2 \times \mathrm{P} 3$ & 8.00 & -0.06 & 110.65 & $6.32 * *$ & 3.08 & 0.01 & 0.74 & 0.02 & 81.29 & $7.38 * *$ \\
\hline $\mathrm{P} 2 \times \mathrm{P} 4$ & 9.97 & $-2.34 * *$ & 163.00 & $-16.00 * *$ & 3.30 & $-0.11^{*}$ & 0.84 & -0.02 & 132.37 & $-16.60 * *$ \\
\hline $\mathrm{P} 2 \times \mathrm{P} 5$ & 8.50 & -0.57 & 138.43 & $-13.46^{* *}$ & 3.50 & -0.00 & 0.82 & $0.04 *$ & 110.85 & $-5.31 * *$ \\
\hline $\mathrm{P} 2 \times \mathrm{P} 6$ & 9.20 & -0.32 & 130.72 & $-22.85 * *$ & 3.64 & -0.09 & 0.83 & $0.06 * *$ & 102.00 & $-22.70 * *$ \\
\hline $\mathrm{P} 3 \times \mathrm{P} 4$ & 8.30 & 0.11 & 108.35 & $-7.32 * *$ & 3.20 & -0.00 & 0.66 & -0.00 & 70.85 & $-5.49 * *$ \\
\hline $\mathrm{P} 3 \times \mathrm{P} 5$ & 7.27 & -0.36 & 98.50 & $-20.01 * *$ & 3.27 & 0.00 & 0.70 & $0.03 *$ & 68.80 & $-9.21 * *$ \\
\hline $\mathrm{P} 3 \times \mathrm{P} 6$ & 7.00 & -0.58 & 112.36 & 0.18 & 2.85 & 0.05 & 0.53 & 0.00 & 59.47 & 0.67 \\
\hline $\mathrm{P} 4 \times \mathrm{P} 5$ & 9.43 & $-0.94 *$ & 155.28 & $-16.38^{* *}$ & 3.17 & $-0.13 * *$ & 0.79 & -0.02 & 120.67 & $-17.53^{* *}$ \\
\hline $\mathrm{P} 4 \times \mathrm{P} 6$ & 8.89 & 0.53 & 130.48 & $-9.14 * *$ & 2.95 & -0.05 & 0.72 & -0.00 & 93.03 & $-7.50 * *$ \\
\hline $\mathrm{P} 5 \times \mathrm{P} 6$ & 10.00 & $-1.10^{* *}$ & 154.19 & $-12.15^{* *}$ & 3.59 & $-0.13 * *$ & 0.78 & $-0.05 * *$ & 125.72 & $-15.41 * *$ \\
\hline \multirow[t]{2}{*}{ SE (sij) } & & 0.295 & & 0.316 & & 0.049 & & 0.017 & & 1.647 \\
\hline & \multicolumn{10}{|c|}{ Reciprocal crosses (RCA) } \\
\hline $\mathrm{P} 2 \times \mathrm{P} 1$ & 12.20 & $0.95 * *$ & 175.03 & $14.25^{* *}$ & 3.97 & $0.09 *$ & 0.92 & $0.07 * *$ & 157.25 & $21.98 * *$ \\
\hline $\mathrm{P} 3 \times \mathrm{P} 1$ & 7.00 & $2.09 * *$ & 101.54 & $26.78 * *$ & 3.06 & $0.25 * *$ & 0.70 & $0.09 * *$ & 70.19 & $32.91 * *$ \\
\hline $\mathrm{P} 4 \times \mathrm{P} 1$ & 10.32 & -0.01 & 132.00 & $-6.50 * *$ & 2.57 & $-0.25 * *$ & 0.76 & 0.00 & 99.27 & $-5.79 * *$ \\
\hline $\mathrm{P} 5 \times \mathrm{P} 1$ & 8.13 & $-1.02 * *$ & 145.00 & $-8.36^{* *}$ & 3.22 & $-0.11^{*}$ & 0.60 & $-0.09 * *$ & 86.67 & $-19.92 * *$ \\
\hline $\mathrm{P} 6 \times \mathrm{P} 1$ & 9.73 & -0.04 & 145.15 & $3.93 * *$ & 3.17 & -0.02 & 0.62 & $-0.07 * *$ & 89.23 & $-7.72 * *$ \\
\hline $\mathrm{P} 3 \times \mathrm{P} 2$ & 8.13 & $-0.58^{*}$ & 98.00 & $-15.08 * *$ & 3.05 & $-0.10^{*}$ & 0.69 & 0.02 & 66.53 & $-10.65 * *$ \\
\hline $\mathrm{P} 4 \times \mathrm{P} 2$ & 14.67 & $2.14 * *$ & 195.00 & $31.54 * *$ & 3.54 & $0.15 * *$ & 0.88 & $0.05 * *$ & 165.58 & $31.57 * *$ \\
\hline $\mathrm{P} 5 \times \mathrm{P} 2$ & 9.65 & $-0.60 *$ & 165.35 & $9.25 * *$ & 3.51 & $0.09 *$ & 0.74 & 0.01 & 121.48 & $5.31 * *$ \\
\hline $\mathrm{P} 6 \times \mathrm{P} 2$ & 9.84 & -0.20 & 176.43 & $13.66^{* *}$ & 3.83 & $0.56^{* *}$ & 0.85 & $0.09 * *$ & 147.40 & $18.71^{* *}$ \\
\hline $\mathrm{P} 4 \times \mathrm{P} 3$ & 8.07 & -0.40 & 123.00 & $-5.57 * *$ & 3.21 & $0.16^{* *}$ & 0.67 & $-0.03^{*}$ & 81.83 & $-9.01 * *$ \\
\hline $\mathrm{P} 5 \times \mathrm{P} 3$ & 8.00 & -0.46 & 138.53 & $2.08 * *$ & 3.25 & 0.06 & 0.63 & 0.00 & 87.22 & -0.78 \\
\hline $\mathrm{P} 6 \times \mathrm{P} 3$ & 8.17 & $-0.55^{*}$ & 112.00 & $-1.52 * *$ & 2.74 & $-0.14 * *$ & 0.52 & $-0.11 * *$ & 58.13 & $-15.12 * *$ \\
\hline $\mathrm{P} 5 \times \mathrm{P} 4$ & 11.32 & $0.75^{* *}$ & 188.05 & $27.19 * *$ & 3.06 & 0.02 & 0.83 & $0.03 *$ & 155.73 & $26.56^{* *}$ \\
\hline $\mathrm{P} 6 \times \mathrm{P} 4$ & 7.82 & $-1.30 * *$ & 148.76 & $-2.12 * *$ & & -0.02 & 0.73 & -0.02 & 108.04 & $-6.23 * *$ \\
\hline $\mathrm{P} 6 \times \mathrm{P} 5$ & 12.20 & $1.93 * *$ & 178.50 & $29.41 * *$ & & $0.26^{* *}$ & 0.88 & $0.11 * *$ & 156.54 & $40.91 * *$ \\
\hline SE (rij) & & 0.251 & & 0.268 & & 0.042 & & 0.015 & & 1.399 \\
\hline
\end{tabular}

* Significant at $5 \%$ level. ** Significant at $1 \%$ level

and these hybrids resulted from low $\times$ high, low $\times$ low, low $\times$ low GCA effects of their parents. The reciprocal hybrids viz., $\mathrm{P}_{5} \times \mathrm{P}_{4}, \mathrm{P}_{6} \times \mathrm{P}_{2}$ and $\mathrm{P}_{6} \times \mathrm{P}_{5}$ were the high performing hybrids based on RCA effects and these hybrids were the outcome of low $\times$ high, high $\times$ low and high $\times$ low GCA effects of their parents. The hybrid viz., $\mathrm{P}_{3} \times \mathrm{P}_{6}, \mathrm{P}_{5} \times \mathrm{P}_{4}, \mathrm{P}_{6} \times \mathrm{P}_{2}$ and $\mathrm{P}_{6} \times \mathrm{P}_{5}$ had one parent as good combiner. Here, the character is under the control of non additive gene action. The per se performance was found to be high for reciprocal cross $\mathrm{P}_{6} \times \mathrm{P}_{5}$ and this cross showed additive $\times$ dominance gene action, the conventional breeding technology needs some modification for capitalizing the genetic effects. In this context, instead of continuous selfing for a number of generations prior to selection, alternate intermating and selfing might be adopted to increase the span of selection. This would enhance the frequency of potential transgressive segregants in such breeding 
Table 8. Per se performance and specific combining ability effects of direct and reciprocal crosses for quality traits

\begin{tabular}{|c|c|c|c|c|c|c|c|c|c|c|}
\hline \multirow{3}{*}{ Hybrids } & \multicolumn{2}{|c|}{ Ascorbic acid } & \multicolumn{2}{|c|}{ Capsaicin } & \multicolumn{2}{|c|}{ Colour value } & \multicolumn{2}{|c|}{ Oleoresin } & \multicolumn{2}{|c|}{ TSS } \\
\hline & \multicolumn{10}{|c|}{ Direct crosses (SCA) } \\
\hline & $\begin{array}{c}\text { Mean } \\
(\mathrm{mg} / \mathbf{1 0 0} \mathrm{g})\end{array}$ & $\begin{array}{l}\text { SCA/ } \\
\text { RCA }\end{array}$ & $\begin{array}{c}\text { Mean } \\
(\%)\end{array}$ & $\begin{array}{l}\text { SCA/ } \\
\text { RCA }\end{array}$ & $\begin{array}{c}\text { Mean } \\
\text { (ASTA) }\end{array}$ & $\begin{array}{l}\text { SCA/ } \\
\text { RCA }\end{array}$ & $\begin{array}{c}\text { Mean } \\
(\%)\end{array}$ & $\begin{array}{l}\text { SCA/ } \\
\text { RCA }\end{array}$ & $\begin{array}{l}\text { Mean } \\
\text { ( }{ }^{\circ} \text { Brix) }\end{array}$ & $\begin{array}{l}\text { SCA/ } \\
\text { RCA }\end{array}$ \\
\hline $\mathrm{P} 1 \times \mathrm{P} 2$ & 104.61 & $-16.98 * *$ & 0.68 & $-0.12 * *$ & 83.54 & $5.81 * *$ & 13.57 & 0.08 & 6.87 & $0.40 * *$ \\
\hline $\mathrm{P} 1 \times \mathrm{P} 3$ & 132.90 & $11.24 * *$ & 0.65 & $0.05^{* *}$ & 72.83 & $3.53 *$ & 14.87 & $0.30 *$ & 7.58 & $0.25^{*}$ \\
\hline $\mathrm{P} 1 \times \mathrm{P} 4$ & 125.02 & $-11.02 * *$ & 0.61 & 0.00 & 92.10 & 1.88 & 14.60 & 0.03 & 7.07 & $-0.21 *$ \\
\hline $\mathrm{P} 1 \times \mathrm{P} 5$ & 98.45 & $-19.50 * *$ & 0.66 & $0.03 *$ & 68.25 & $-4.59 * *$ & 13.41 & $0.58 * *$ & 6.18 & 0.18 \\
\hline $\mathrm{P} 1 \times \mathrm{P} 6$ & 115.53 & $-4.50 * *$ & 0.73 & 0.00 & 94.98 & 1.63 & 13.06 & $-0.52 * *$ & 6.93 & 0.14 \\
\hline $\mathrm{P} 2 \times \mathrm{P} 3$ & 138.32 & $20.35 * *$ & 0.61 & $0.06^{* *}$ & 86.10 & 0.08 & 13.70 & 0.13 & 6.30 & $-0.39 * *$ \\
\hline $\mathrm{P} 2 \times \mathrm{P} 4$ & 124.46 & $-9.53 * *$ & 0.63 & $-0.06^{* *}$ & 111.79 & $12.33^{* *}$ & 15.97 & $0.79 * *$ & 7.63 & $0.71 * *$ \\
\hline $\mathrm{P} 2 \times \mathrm{P} 5$ & 85.70 & $-10.39 * *$ & 0.75 & $0.07 * *$ & 76.83 & $3.12 *$ & 14.46 & $0.44 * *$ & 6.50 & 0.17 \\
\hline $\mathrm{P} 2 \times \mathrm{P} 6$ & 130.68 & $-13.89 * *$ & 0.58 & $-0.08 * *$ & 95.50 & $4.54 * *$ & 14.10 & -0.01 & 6.07 & $-0.27 * *$ \\
\hline $\mathrm{P} 3 \times \mathrm{P} 4$ & 138.35 & $4.88 * *$ & 0.58 & $-0.03 * *$ & 87.91 & 0.31 & 14.45 & 0.01 & 6.37 & 0.18 \\
\hline $\mathrm{P} 3 \times \mathrm{P} 5$ & 122.67 & $10.40 * *$ & 0.64 & $0.08 * *$ & 80.10 & $5.67 * *$ & 13.59 & $-0.63 * *$ & 5.58 & $-0.73 * *$ \\
\hline $\mathrm{P} 3 \times \mathrm{P} 6$ & 158.39 & $20.36 * *$ & 0.62 & 0.02 & 94.62 & -0.26 & 13.84 & $0.77 * *$ & 6.84 & -0.17 \\
\hline $\mathrm{P} 4 \times \mathrm{P} 5$ & 127.51 & $-14.05 * *$ & 0.60 & 0.02 & 81.42 & $5.11 * *$ & 14.73 & 0.16 & 6.73 & $0.42 * *$ \\
\hline $\mathrm{P} 4 \times \mathrm{P} 6$ & 134.59 & -0.83 & 0.65 & 0.02 & 95.25 & $4.35 * *$ & 14.98 & -0.08 & 7.07 & 0.03 \\
\hline $\mathrm{P} 5 \times \mathrm{P} 6$ & 103.71 & $-30.28 * *$ & 0.63 & $-0.08 * *$ & 105.68 & $14.08 * *$ & 12.74 & 0.28 & 7.30 & $0.73 * *$ \\
\hline \multirow[t]{2}{*}{ SE (sij) } & & 0.861 & & 0.013 & & 1.349 & & 0.144 & & 0.113 \\
\hline & \multicolumn{10}{|c|}{ Reciprocal crosses (RCA) } \\
\hline $\mathrm{P} 2 \times \mathrm{P} 1$ & 138.57 & -0.10 & 0.93 & $0.11^{* *}$ & 92.65 & $-4.55 * *$ & 13.06 & $-1.00 * *$ & 6.93 & -0.21 \\
\hline $\mathrm{P} 3 \times \mathrm{P} 1$ & 110.41 & 0.42 & 0.54 & -0.01 & 91.48 & $-9.32 * *$ & 14.58 & 0.14 & 6.28 & $0.65 * *$ \\
\hline $\mathrm{P} 4 \times \mathrm{P} 1$ & 147.08 & $3.93 *$ & 0.61 & $-0.06^{* *}$ & 93.94 & -0.92 & 16.09 & $-0.74 * *$ & 6.60 & 0.23 \\
\hline $\mathrm{P} 5 \times \mathrm{P} 1$ & 137.47 & $5.10 * *$ & 0.59 & -0.01 & 72.83 & -2.29 & 16.35 & $-1.47 * *$ & 6.90 & $-0.36^{* *}$ \\
\hline $\mathrm{P} 6 \times \mathrm{P} 1$ & 124.54 & $-10.05 * *$ & 0.72 & 0.00 & 94.42 & 0.27 & 14.95 & $-0.94 * *$ & 7.18 & -0.12 \\
\hline $\mathrm{P} 3 \times \mathrm{P} 2$ & 97.62 & $-2.23 *$ & 0.47 & $-0.03 * *$ & 75.69 & $5.20 * *$ & 14.27 & -0.28 & 5.43 & $0.43 * *$ \\
\hline $\mathrm{P} 4 \times \mathrm{P} 2$ & 143.52 & $2.90 * *$ & 0.76 & $0.05^{* *}$ & 99.53 & $6.12 * *$ & 15.08 & $0.44 *$ & 7.06 & $0.28^{*}$ \\
\hline $\mathrm{P} 5 \times \mathrm{P} 2$ & 106.50 & $-15.71 * *$ & 0.53 & -0.00 & 84.08 & $-3.62^{*}$ & 13.86 & 0.30 & 5.73 & $0.38 * *$ \\
\hline $\mathrm{P} 6 \times \mathrm{P} 2$ & 158.48 & $15.51 * *$ & 0.67 & -0.02 & 104.13 & $-4.31 * *$ & 13.76 & 0.16 & 6.73 & -0.14 \\
\hline $\mathrm{P} 4 \times \mathrm{P} 3$ & 128.59 & $2.84 * *$ & 0.65 & $0.04 * *$ & 92.04 & -2.06 & 14.91 & -0.23 & 7.27 & $-0.44 * *$ \\
\hline $\mathrm{P} 5 \times \mathrm{P} 3$ & 101.86 & 0.91 & 0.48 & $0.03^{*}$ & 78.58 & 0.76 & 12.46 & $0.56^{* *}$ & 4.83 & $0.37 * *$ \\
\hline $\mathrm{P} 6 \times \mathrm{P} 3$ & 117.67 & $9.42 * *$ & 0.58 & -0.01 & 88.04 & $3.29 *$ & 15.48 & -0.82 & 5.80 & $0.52 * *$ \\
\hline $\mathrm{P} 5 \times \mathrm{P} 4$ & 155.62 & $19.32 * *$ & 0.55 & -0.02 & 101.17 & $-9.87 * *$ & 14.68 & 0.02 & 6.74 & -0.00 \\
\hline $\mathrm{P} 6 \times \mathrm{P} 4$ & 136.25 & $-4.06^{* *}$ & 0.61 & $-0.04 * *$ & 121.68 & $-13.21 * *$ & 14.38 & 0.30 & 6.73 & $0.17^{* *}$ \\
\hline $\mathrm{P} 6 \times \mathrm{P} 5$ & 164.28 & $13.78 * *$ & 0.79 & $0.06^{* *}$ & 98.72 & $3.47 *$ & 15.35 & $-1.30 * *$ & 6.51 & 0.39 \\
\hline SE (rij) & & 0.731 & & 0.011 & & 1.588 & & 0.169 & & 0.133 \\
\hline
\end{tabular}

* Significant at 5\% level. ** Significant at $1 \%$ level

materials. These results are in corroboration with findings of Geleta \& Labuschagne (2006) and Khalil \& Hatem (2014).

The best performing hybrids for capsaicin content based on SCA effects were $\mathrm{P} 3 \times \mathrm{P} 5, \mathrm{P} 2 \times \mathrm{P} 5$ and $\mathrm{P} 2 \times \mathrm{P} 3$ and these hybrids were resultant of low $\times$ high, high $\times$ low and high $\times$ low GCA effects of their parents. The reciprocal hybrids viz., $\mathrm{P} 2 \times \mathrm{P} 1, \mathrm{P} 6 \times \mathrm{P} 5$ and $\mathrm{P} 4 \times$ $\mathrm{P} 2$ were the high performing hybrids based on RCA effects and these hybrids were the outcome of high $\times$ high, high $\times$ low and low $\times$ high GCA effects of their respective parents. The combination $\mathrm{P} 2 \times \mathrm{P} 1$ registered the highest positive SCA (Table 8), which is a representation of high (positive) $\times$ high (positive) GCA combination suggesting additive $\times$ additive gene interaction. This hybrid would throw desirable segregants as the additive gene effects are fixable. This was closely followed by the cross $\mathrm{P}_{3} \times \mathrm{P}_{5}$ representing 
Table 9. Best performing F1 hybrids for fruit yield and quality traits in chilli

\begin{tabular}{|c|c|c|}
\hline \multirow[t]{3}{*}{ Based on per se } & $\begin{array}{l}\text { Number of fruits, individual fresh and dry } \\
\text { pod weight and yield }\end{array}$ & $\mathrm{P} 4 \times \mathrm{P} 2, \mathrm{P} 2 \times \mathrm{P} 1, \mathrm{P} 6 \times \mathrm{P} 5$ \\
\hline & Fruit yield and quality & $\mathrm{P} 6 \times \mathrm{P} 5, \mathrm{P} 4 \times \mathrm{P} 2, \mathrm{P} 2 \times \mathrm{P} 1$ \\
\hline & $\begin{array}{l}\text { Number of fruits, individual fresh and dry pod } \\
\text { weight, fruit yield and quality }\end{array}$ & $\mathrm{P} 6 \times \mathrm{P} 5, \mathrm{P} 4 \times \mathrm{P} 2, \mathrm{P} 2 \times \mathrm{P} 1$ \\
\hline \multirow[t]{3}{*}{ Based on SCA (direct crosses) } & $\begin{array}{l}\text { Number of fruits, individual fresh and dry pod } \\
\text { weight and yield }\end{array}$ & $\mathrm{P} 1 \times \mathrm{P} 3, \mathrm{P} 2 \times \mathrm{P} 3, \mathrm{P} 3 \times \mathrm{P} 6$ \\
\hline & Fruit yield and quality & $\mathrm{P} 3 \times \mathrm{P} 6, \mathrm{P} 2 \times \mathrm{P} 4, \mathrm{P} 1 \times \mathrm{P} 3$ \\
\hline & $\begin{array}{l}\text { Number of fruits, individual fresh and dry pod } \\
\text { weight, fruit yield and quality }\end{array}$ & $\mathrm{P} 1 \times \mathrm{P} 3, \mathrm{P} 3 \times \mathrm{P} 6$ \\
\hline \multirow[t]{3}{*}{ Based on RCA (reciprocal crosses) } & $\begin{array}{l}\text { Number of fruits, individual fresh and dry pod } \\
\text { weight and yield }\end{array}$ & $\mathrm{P} 6 \times \mathrm{P} 5, \mathrm{P} 4 \times \mathrm{P} 2, \mathrm{P} 3 \times \mathrm{P} 1$ \\
\hline & Fruit yield and quality & $\mathrm{P} 6 \times \mathrm{P} 5, \mathrm{P} 4 \times \mathrm{P} 2, \mathrm{P} 3 \times \mathrm{P} 2$ \\
\hline & $\begin{array}{l}\text { Number of fruits, individual fresh and dry pod } \\
\text { weight, fruit yield and quality }\end{array}$ & $\mathrm{P} 6 \times \mathrm{P} 5, \mathrm{P} 4 \times \mathrm{P} 2$ \\
\hline \multirow[t]{3}{*}{ Based on heterosis over check hybrid } & $\begin{array}{l}\text { Number of fruits, individual fresh and dry pod } \\
\text { weight and yield }\end{array}$ & $\mathrm{P} 4 \times \mathrm{P} 2, \mathrm{P} 6 \times \mathrm{P} 5, \mathrm{P} 2 \times \mathrm{P} 1$ \\
\hline & Fruit yield and quality & $\mathrm{P} 6 \times \mathrm{P} 5, \mathrm{P} 2 \times \mathrm{P} 4, \mathrm{P} 2 \times \mathrm{P} 1$ \\
\hline & $\begin{array}{l}\text { Number of fruits, individual fresh and dry } \\
\text { pod weight, fruit yield and quality }\end{array}$ & $\mathrm{P} 6 \times \mathrm{P} 5, \mathrm{P} 2 \times \mathrm{P} 1$ \\
\hline
\end{tabular}

a low (negative) $\times$ low (negative) GCA combination suggesting the action of epistasis gene action. While the cross $\mathrm{P}_{6} \times \mathrm{P}_{5}, \mathrm{P}_{2} \times \mathrm{P}_{5}$ and $\mathrm{P}_{2} \times \mathrm{P}_{3}$ represents a high $\times$ low GCA combination probably by additive $\times$ dominant interaction. These hybrids had the greatest chance of producing transgressive segregants in later generation. These results were in conformity to the findings of Prasath \& Ponnuswami (2008), Jaya Rame Gowda (2009), Savitha (2011) and Munish Sharma (2012).

In a breeding programme of hot pepper with the aim to improve the total extractable colour yield, it is not sufficient to develop genotypes with high fruit yield alone. For colour value, hybrids $\mathrm{P}_{5} \times \mathrm{P}_{6}, \mathrm{P}_{2} \times \mathrm{P}_{4}$ and $\mathrm{P}_{1} \times \mathrm{P}_{2}$ were best performing based on SCA effects and these were resultant of low $\times$ high, low $\times$ high and low $\times$ low GCA effects of their parents. The reciprocal hybrids viz., $\mathrm{P}_{4} \times \mathrm{P}_{2}, \mathrm{P}_{3} \times \mathrm{P}_{2}$ and $\mathrm{P}_{6} \times \mathrm{P}_{5}$ were the high performing hybrids based on RCA effects and these hybrids were the outcome of high $\times$ low, low $\times$ low and high $\times$ low GCA effects of their respective parents. The per se performance was found to be high in the cross $\mathrm{P}_{2} \times \mathrm{P}_{4}$ and showed dominant $\times$ additive gene action. For the cross $\mathrm{P}_{2} \times \mathrm{P}_{4}$ selection for this trait could be postponed to later generations in recombination breeding. These results are in accordance with the findings of Prasath \& Ponnuswami (2008); Savitha (2011).

The best performing hybrids based on SCA effects were $\mathrm{P}_{2} \times \mathrm{P}_{4}, \mathrm{P}_{3} \times \mathrm{P}_{6}$ and $\mathrm{P}_{1} \times \mathrm{P}_{5}$. These hybrids were the outcome of low $\times$ high, low $\times$ low and high $\times$ low GCA effects of their respective parents for oleoresin. The reciprocal hybrids viz., $\mathrm{P}_{5} \times \mathrm{P}_{3}$ and $\mathrm{P}_{4} \times \mathrm{P}_{2}$ were the best performing hybrids based on RCA effects and these hybrids were the outcome of low $\times$ low and high $\times$ low GCA effects of their respective parents. The per se performance were found to be high for direct cross $\mathrm{P} 2 \times \mathrm{P} 4$ and this cross showed dominance $\times$ additive gene action and to exploit this genetic variance, conventional breeding procedures such as pedigree selection could be worthful. These results were in conformity with the findings of Saritha et al. (2005), Savitha (2011) and Munish Sharma (2012).

The hybrids $\mathrm{P}_{5} \times \mathrm{P}_{6}, \mathrm{P}_{2} \times \mathrm{P}_{4}$ and $\mathrm{P}_{1} \times \mathrm{P}_{3}$ were found to be superior hybrids based on their SCA effects and per se performance for total soluble solids content. These hybrids were the products of low $\times$ high, low $\times$ high and high $\times$ low GCA effects of their individual parents. The reciprocal hybrids viz., $\mathrm{P}_{3} \times \mathrm{P}_{1}, \mathrm{P}_{6} \times \mathrm{P}_{3}$ and $\mathrm{P}_{3} \times \mathrm{P}_{2}$ were the best performing hybrids based on RCA effects and these hybrids were the outcome of low $\times$ high, high $\times$ low and low $\times$ low GCA effects of their respective parents. The per se performance was found to be high for direct crosses $\mathrm{P}_{2} \times \mathrm{P}_{4}$ and $\mathrm{P}_{5} \times \mathrm{P}_{6}$ which showed dominance $\times$ additive gene action. Hence biparental breeding would be effective for exploitation of this trait. These hybrids could produce desirable transgressive segregants in the advanced generation. For harnessing non additive gene action in these hybrids, cyclic method of breeding involving selected recombinants and their inter crossing would be more desirable for improving total soluble solids content. Present results were in conformity with finding of Khalil \& Hatem (2014). 
Table 10. Promising $F_{1}$ hybrids for fruits, quality and high yield in chilli

\begin{tabular}{ll}
\hline $\begin{array}{l}\text { Number of fruits, individual fresh } \\
\text { and dry pod weight, and yield }\end{array}$ & $\mathrm{P} 4 \times \mathrm{P} 2, \mathrm{P} 6 \times \mathrm{P} 5, \mathrm{P} 2 \times \mathrm{P} 1$ \\
$\begin{array}{l}\text { Number of fruits, individual fresh } \\
\text { and dry pod weight, quality and } \\
\text { yield }\end{array}$ & $\mathrm{P} 2 \times \mathrm{P} 1, \mathrm{P} 4 \times \mathrm{P} 2$ \\
$\begin{array}{l}\text { Quality and yield } \\
\mathrm{P} 2 \times \mathrm{P} 1\end{array}$
\end{tabular}

The $F_{1}$ combinations that surpassed their parents for maximum number of components of merit were $\mathrm{P}_{4} \times \mathrm{P}_{2} \quad($ LCA625 $\times \mathrm{K} 1), \quad \mathrm{P}_{2} \times \mathrm{P}_{1}$ (K1 $\times$ Arka Lohit), $\mathrm{P}_{6} \times \mathrm{P}_{5} \quad$ (Pusa Jwala $\left.\times \mathrm{PKM} 1\right)$, $\mathrm{P} 1 \times \mathrm{P} 3$ (Arka Lohit $\times$ LCA334) and $\mathrm{P} 2 \times \mathrm{P} 4$ (K1 $\times$ LCA625). Further, it was also found that the hybrids $\mathrm{P}_{4} \times \mathrm{P}_{2}($ LCA625 $\times \mathrm{K} 1)$ and $\mathrm{P}_{6} \times \mathrm{P}_{5}$ (Pusa Jwala $\times$ PKM1) were adjudged as the best crosses based on their number of fruits, individual dry weight and yield which are considered as the main objectives of development of hybrids with high yield and quality. The next best hybrid was $\mathrm{P}_{1} \times \mathrm{P}_{3}$ (Arka Lohit $\times$ LCA334) as evidenced from better scores of number of fruits, fruit length, yield and quality traits. For quality improvement coupled with yield enhancement, the cross $\mathrm{P}_{2} \times \mathrm{P}_{1} \quad(\mathrm{~K} 1 \times$ Arka Lohit $)$ was found to be best as evidenced from the scores obtained for all quality traits and yield in the present investigation (Tables 9 and 10).

In conclusion, analysis of the GCA effects of parents for ten traits studied revealed that $\mathrm{P}_{4}$ (LCA625), $\mathrm{P}_{2}$ (K1) and $\mathrm{P}_{5}$ (PKM1) were the best general combiners for almost all the traits. The hybrids $\mathrm{P}_{4} \times \mathrm{P}_{2}(\mathrm{LCA} 625 \times \mathrm{K} 1), \mathrm{P}_{2} \times \mathrm{P}_{1}(\mathrm{~K} 1 \times$ Arka Lohit $)$ and $\mathrm{P}_{6} \times \mathrm{P}_{5}$ (Pusa Jwala $\times \mathrm{PKM} 1$ ) were found to be the best combiners for yield and its attributes. The hybrid $\mathrm{P}_{2} \times \mathrm{P}_{1}$ (K1×Arka Lohit) was the best reciprocal combiner for quality parameters based on their better mean performance and combing ability. Significant SCA and per se performance of hybrids $\mathrm{P}_{4} \times \mathrm{P}_{2}, \mathrm{P}_{2} \times \mathrm{P}_{1}$ and $\mathrm{P}_{6} \times \mathrm{P}_{5}$ indicates there is an opportunity for developing F1 Hybrids. Further, isolation will enhance the genetic base of the populations by finding new recombinants to increase the yield and fruit quality.

\section{References}

Asish Ghosh, 2005. Studies on the improvement of CO 4 vegetable chilli (Capsicum annuum L.) through hybridization. M.Sc. (Hort.) Thesis, Tamil Nadu Agric Univ, Coimbatore, India.

CBG, 2013. Crop production techniques of horticultural crops. Horticultural College and Research Institute, Tamil Nadu Agric Univ, Coimbatore, India.
Dhillon BS, 1975. The application of partial diallel crosses in plant breeding-A review. J Crop Improv 2: 1-7.

Geleta LF, Labuschagne MT, 2006. Combining ability and heritability for vitamin $\mathrm{C}$ and total soluble solids in pepper (Capsicum annuum L.). J Sci Food Agr 86: 1317-1320.

Gilbert NE, 1958. Diallel cross in plant breeding. Heredity 12: 477-492. https://doi.org/10.1038/hdy.1958.48

Gill HS, Thakur PC, Thakur TC, 1973. Combining ability in sweet pepper (Capsicum annuum L. var. grossum Sandt.). Ind J Agric Sci 43 (16): 918-921.

Griffing B, 1956. Generalized treatments of the use of diallel cross in quantitative inheritance. Heredity 10: 31-50. https://doi.org/10.1038/hdy.1956.2

Hayman BI, 1957. Interaction, heterosis and diallel cross. Genetics 42: 336-355.

Jagadeesha RC, Wali MC, 2008. Combining ability for fruit quality parameters in chilli (Capsicum annuum L.). Asian J Hortic 3 (2): 217-221.

Jaya Rame Gowda R, 2009. Breeding for yield and resistance to chilli thrips (Scirtothrips dorsalis and Polyphagotarsonemus latus Banks) in chilli (Capsicum annuum). M.Sc. Thesis, Kerala Agric Univ, Thrissur, India

Kadambavanasundaram M, 1980. Heterotic system in cultivated species of Gossypium. An appraisal (Abst). Genetic and crop improvement of heterotic systems. Precongress scientific meeting of XV International Congress of Genetics, TNAU, Coimbatore, pp. 20.

Khalil MR, Hatem MK, 2014. Study on combining ability and heterosis of yield and its components in pepper (Capsicum annum L.). Alexantia J Agric Res 59 (1): 61-71.

Khereba AH, Gharib AA, Mahmood SM, Ahmed YM, Sayed AA, 2008. A study on the combining ability in chilli pepper (Capsicum annuum L. and Capsicum chinense Jacq.) using line $\mathrm{x}$ tester analysis. Cairo University, Bull Fac Agric 59 (2): 116-122.

Manjula B, Ramachandra, Udaykumar, Nidoni, Devadattam SK, 2011. Drying chrematistics of Byadagi chilli (Capsicum annuum L.) using solar tunnel dryer. J Agric Food Tech 1 (4): 34-42.

Mathai CK, 1988. A modified extraction and estimation method of oleoresin and piperin in pepper. Ind Spices 25 (2-3): 3-5.

Munish Sharma, 2012. Heterosis and gene action studies for fruit yield and horticultural traits in chilli (Capsicum annuum var. annuum L.). Ph. D. Thesis. Chaudhary Sarwan Kumar Himachal Pradesh Krishi Vishvavidyalaya, Palampur, India.

Nascimento NFF, Rego ER, Nascimento MF, Bruckner CH, Finger FL, Rego MM, 2014. Combining ability for yield and fruit quality in the pepper (Capsicum annuum). Genet Mol Res 13 (2): 3237-3249. https://doi.org/10.4238/2014. April.29.2

Panse VG, Sukhatme PV, 1957. Statistical methods for agricultural workers. Indian Council of Agricultural Research, New Delhi. pp. 97. 
Prasath D, Ponnuswami V, 2008. Heterosis and combining ability for morphological, yield and quality characters in paprika type chilli hybrids. Ind J Hortic 65 (4): 441-445.

Rego ER, Rego MM, Finger FL, Cruz CD, Casali DA, 2009. Diallel study of yield components and fruit quality in chilli pepper (Capsicum baccatum). Euphytica 168 (2): 275-287. https://doi.org/10.1007/s10681-009-9947-y

Rodríguez, 2003. Performance of hybrid segregating populations of pepino (Solanum muricatum) and its relation to genetic distance among parents. J Hortic Sci Biotech 78: 911-918. https://doi.org/10.1080/14620316.2 003.11511718

Rodríguez, 2008. Performance of hybrids of eggplant (Solanum melongena) and its relation to mid-parent value and to genetic and morphological distances among parents. Eur J Hortic Sci 73 (2): 76-83.

Rohini N, 2015. Genetic anlaysis in F1 and F2 generations of chilli (Capsicum annuum L.). Ph.D (Hort.) Thesis. Tamil Nadu Agric Univ, Coimbatore, India.

Roja BA, Sprague GF, 1952. Comparison of variance components in corn yield trails. III. General and specific combining ability and their interactions with locations and years. Agron J 44: 462-466. https://doi.org/10.2134/ agronj 1952.00021962004400090002x

Sadasivam S, Manickam A, 1992. Biochemical methods for agricultural sciences, Wiley Eastern Ltd, Madras. pp. 201.

Saritha JK, Kulkarni RS, Rao AM, Manjunath A, 2005. Genetic divergence as a function of combining ability in chilli (Capsicum annuum L). Ind J Genet P1 Breed 65 (4): 331-332.

Savitha BK, 2011. Studies on heterosis, combining ability and generation mean analysis for yield and thrips tolerance in chilli (Capsicum annuum L.). Ph.D. Thesis, Tamil Nadu Agric Univ, Coimbatore, India.

Sharanakumar H, Naik MK, Anantachar M, 2011. Drying characteristics of Byadagi chilli (C.annuum L.) Using solar tunnel dryer. J Agr Food Technol 1 (4): 38-42.

Singh SSBJ, 1994. Genetic studies in chilli (C. annuum L.) for early and total yield. Veg Sci 21 (1): 72-76.

Sitaresmi T, Sujiprihati S, Syukur M, 2010. Combining ability of several introduced and local chilli pepper (Capsicum annuum L.) genotypes and heterosis of the off springs. J Agron Indonesia 38 (3): 212.

Somashekhar S, Patil A, Salimath PM, 2008. Estimation of gene effects for fruit yield and its components in chilli (Capsicum annuum L.). Karnataka J Agric Sci 21 (2): 181-183.

Sprague GF, Tatum LA, 1942. General vs specific combining ability in single cross of corn. $\mathrm{J}$ Am Soc Agron 34: 923-932. https://doi.org/10.2134/ agronj1942.00021962003400100008x

Thakur PC, Gill HS, Phagchandani PM, 1980. Diallel analysis of some quantitative traits in sweet pepper. Ind J Agric Sci 50 (11): 811-817.

Woodbury EJ, 1997. Extractable colour of capsicum and oleoresin paprika. JAOAC 60 (1): 1-4. 